ISSN: 2231-3354

Received on: 18-05-2012

Revised on: 25-05-2012

Accepted on: 14-06-2012

DO: 10.7324/J APS.2012.2736
Gurmeet Singh, Dinesh Kumar, Deapak Sharma, Mankaran Singh and Sukhbir Kaur

Department of $\mathrm{P}$ harmaceutics, CT I nstitute of Pharmacentical Sciences Shahpur, J alandhar -144020, Punjab, India.

\author{
For Correspondence \\ Gurmet Singh \\ Department of Pharmaceutics, \\ CT Institute of Pharmaceutical \\ Sciences Shahpur, P. O- U dopur, \\ Near Lambra, J alandhar -144020, \\ Punjab, India.
}

\section{Q-Absorbance Ratio Spectrophotometric Method for the Simultaneous Estimation of Predhisolone and 5-Amino Salicylic Acid in Tablet Dosageform}

\author{
Gurmet Singh, Dinesh Kumar, Deapak Sharma, Mankaran Singh and \\ Sukhbir Kaur
}

\begin{abstract}
The present work carries an analytical method development of prednisolone and 5amino salicylic acid in tablet dosage form. The method is based upon Q - absorption ratio method for the simultaneous determination of the prednisolone and 5-amino salicylic acid. Both the drugs are widely used for bacterial cure and are recommended for the patients with mild to moderate inflammation of the digestive tract. Ulcerative colitis and crohn's disease are the target disorders which are treated by both drug candidates. Absorption ratio method is used for the ratio of the absorption at two selected wavelength one of which is the iso-absorptive point and other being the $\lambda \max$ of one of the two components. Prednisolone and 5-ASA shows their iso-absorptive point at $283 \mathrm{~nm}$ in ethanol and $0.1 \mathrm{~N} \mathrm{HCl}$ respectively. The second wavelength used is $302 \mathrm{~nm}$ which is the $\lambda \max$ of 5 -ASA in $0.1 \mathrm{~N} \mathrm{HCl}$. The linearity was obtained in the concentration range of $1-10 \mu \mathrm{g} / \mathrm{ml}$ for prednisolone and 5-ASA. This method was applied to all pharmaceutical dosage form because there is no excipients interference between them. The results have been validated by recovery studies.
\end{abstract}

Kevwords: Prednisolone. 5-ASA. absorption ratio method. linearitv. $\lambda$ max.

\section{INTRODUCTION}

5-Amino salicylic acid is an anti-inflammatory drug. It has been used to treat inflammatory bowel disease, such as ulcerative colitis and mild to moderate crohn's disease. Chemically, called as 5-Amino-2-hydroxybenzoic acid and molecular formula is $\mathrm{C}_{7} \mathrm{H}_{7} \mathrm{NO}_{3}$ (as shown in figure 1). It is soluble in $0.1 \mathrm{~N} \mathrm{HCl}$, sparingly soluble in hot water, slightly soluble in cold water and alcohol. Prednisolone is an adrenocortical steroid. Chemically called $11 \beta, 17 \alpha$, 21-trihydroxy-1,4-Pregnadiene-3,20-dione molecular formula is $\mathrm{C}_{21} \mathrm{H}_{28} \mathrm{O}_{5}$ (as shown in figure 2). It is soluble in ethanol (95\%) and in methanol, sparingly soluble in acetone, slightly soluble in chloroform, very slightly soluble in water (I.P., 1996). 


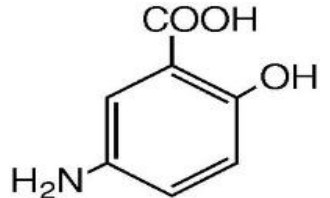

Fig.1: Structure of 5 - ASA

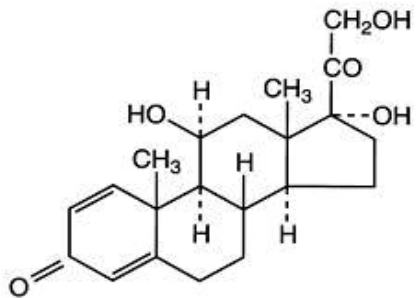

Fig. 2: Structure of Prednisolone.

Ultraviolet and visible spectrophotometry is one of the most frequently employed analytical tools in the pharmaceutical industry. Spectrophotometry is mainly concerned with the following regions of spectrum: ultraviolet, visible and infrared (Mendham et al., 2004). Ultraviolet and visible absorption spectrophotometry involves the measurement of the absorption of monochromatic radiation by solutions of chemical substances, in the range of $185 \mathrm{~nm}$ to $380 \mathrm{~nm}$, and $380 \mathrm{~nm}$ to $780 \mathrm{~nm}$ of the spectrum, respectively (I.P., 2007). The amount of absorption depends on the wavelength of radiation and the structure of the compound. The absorption of radiation is due to the subtraction of energy from the radiation beam when electrons in orbital of lower energy are excited into orbital of higher energy.

Since, it is an electron transition phenomenon; UV is sometimes called electronic spectroscopy (Kalsi, 2002). The various spectro-photometric method which are used for estimation of drug in combine dosage form includes;

- Simultaneous equation method

- Absorption ratio method (Q-ratio method)

- Geometric correction method

- Orthogonal polynomial method

- Difference spectrophotometry

- Derivative spectrophotometery

- Chemical derivatisation

- Absorption correction method

- Multicomponent method of analysis (Beckett and Stenlake, 2005).

\section{Q-ABSORPTION RATIO METHOD}

\section{Let it be one drug $X$ and $Y$}

According to Q-Absorption ratio method, use the ratio of absorption at two selected wavelengths. One is at iso-absorptive point and other being the $\lambda$ max of one of the two components.

Two equations were constructed as described below, using the relationship $\mathrm{ax}_{1}=\mathrm{ay}_{1}$ at $\lambda_{1}$ and $\mathrm{L}=1$. Equations are;

At $\lambda_{1} \quad \mathrm{~A}_{1}=\mathrm{ax}_{1} \mathrm{Cx}+\mathrm{ax}_{1} \mathrm{Cy}$ (because $\mathrm{ax}_{1}=\mathrm{ay}_{1}$ )

At $\lambda_{2} \quad \mathrm{~A}_{2}=\mathrm{ax}_{2} \mathrm{Cx}+\mathrm{ay}_{2} \mathrm{Cy}$
$\mathrm{A}_{2} / \mathrm{A}_{1}=\left(\mathrm{ax}_{2} \mathrm{Cx}+\mathrm{ay}_{2} \mathrm{Cy}\right) /\left(\mathrm{ax}_{1} \mathrm{Cx}+\mathrm{ax}_{1} \mathrm{Cy}\right)$

Let $\mathrm{Cx} /(\mathrm{Cx}+\mathrm{Cy})=\mathrm{Fx} \& \mathrm{Cy} /(\mathrm{Cx}+\mathrm{Cy})=\mathrm{Fy}$

Dividing Equation (3) by $\mathrm{Cx}+\mathrm{Cy}$, we get

$\mathrm{A}_{2} / \mathrm{A}_{1}=\left(\mathrm{ax}_{2} \mathrm{Fx}+\mathrm{ay}_{2} \mathrm{Fy}\right) /\left(\mathrm{ax}_{1} \mathrm{Fx}+\mathrm{ax}_{1} \mathrm{Fy}\right)$

But $\mathrm{Fy}=1-\mathrm{Fx}$

$\mathrm{A}_{2} / \mathrm{A}_{1}=\left(\mathrm{ax}_{2} \mathrm{Fx}+\mathrm{ay}_{2}-\mathrm{ay}_{2} \mathrm{Fx}\right) / \mathrm{ax}_{1}$

$\mathrm{A}_{2} / \mathrm{A}_{1}=\left(\mathrm{ax}_{2} \mathrm{Fx} / \mathrm{ax}_{1}\right)-\left(\mathrm{ay}_{2} \mathrm{Fx} / \mathrm{ay}_{1}\right)+\left(\mathrm{ay}_{2} / \mathrm{ay}_{1}\right)\left(\right.$ because $\left.\mathrm{ax}_{1}=\mathrm{ay}_{1}\right)$

Let $\mathrm{ax}_{2} / \mathrm{ax}_{1}=\mathrm{Qx}, \mathrm{ay}_{2} / \mathrm{ay}_{1}=\mathrm{Qy} \& \mathrm{~A}_{2} / \mathrm{A}_{1}=\mathrm{QM}_{\mathrm{M}}$

So, $Q_{M}=F x Q x-F y Q y+Q y$

$\mathrm{Fx}=\left(\mathrm{Q}_{\mathrm{M}}-\mathrm{Qy}\right) /(\mathrm{Qx}-\mathrm{Qy})$

This equation gives the fraction of mixture that determine the absolute concentration of $\mathrm{X}$ and $\mathrm{Y}$.

$\mathrm{Cx} /(\mathrm{Cx}=\mathrm{Cy})=\left(\mathrm{A}_{2} / \mathrm{A}_{1}\right)-\left(\mathrm{ay}_{2} / \mathrm{ay}_{1}\right) /\left(\mathrm{ax}_{2} / \mathrm{ax}_{1}\right)-\left(\mathrm{ay}_{2} / \mathrm{ay}_{1}\right)$

Both equation (5) \& (6) gives the fraction, rather than the concentration of $\mathrm{X}$ and consequently of $\mathrm{Y}$ in the mixture in the term of absolute ratio. As, these are independent of concentration only approximate rather than accurate.

If the absolute concentration of $\mathrm{X} \& \mathrm{Y}$ than rearrange equation (1), we get

$\mathrm{Cx}+\mathrm{Cy}=\mathrm{A}_{1} / \mathrm{ax}_{1}$

From equation (6) \& (7), we get

$\mathrm{Cx} /\left(\mathrm{A}_{1} / \mathrm{ax}_{1}\right)=\left(\mathrm{Q}_{\mathrm{M}}-\mathrm{Qy}\right) /(\mathrm{Qx}-\mathrm{Qy})$

$\mathrm{Cx}=\left\{\left(\mathrm{Q}_{\mathrm{M}}-\mathrm{Qy}\right) /(\mathrm{Qx}-\mathrm{Qy})\right\}^{*}\left(\mathrm{~A}_{1} / \mathrm{ax}_{1}\right)$

$\& \mathrm{Cy}=\left\{\left(\mathrm{Q}_{\mathrm{M}}-\mathrm{Qx}\right) /(\mathrm{Qy}-\mathrm{Qx})\right\} *\left(\mathrm{~A}_{1} / \mathrm{ay}_{1}\right)$

Finally equation $(8 \& 9)$ gives the absolute concentration value of drug X \& Y (Beckett and Stenlake, 2005).

\section{MATERIAL AND METHOD}

The 5-Amino salicylic acid (5-ASA) was purchased from Himedia Laboratories, Mumbai (INDIA) and Prednisolone was supplied as a gift sample by La-Pharma, Ludhiana (INDIA). All other chemicals and reagents used were of analytical grade.

\section{Apparatus and conditions}

A double beam Shimadzu UV-1800 series spectrophotometer was used. Absorption and overlain spectra of both test and standard solutions were recorded over the wavelength range of 200-400nm using $1 \mathrm{~cm}$ quartz cell at fast scanned speed and fixed slit width of $1.0 \mathrm{~nm}$. All weighing of ingredients were done on ohaus digital weighing balance.

\section{Preparation of standard stock solution}

Stock solution $(1000 \mu \mathrm{g} / \mathrm{ml})$ of 5-amino salicylic acid (5ASA) and prednisolone were prepared by accurately weighing 100 $\mathrm{mg}$ of the drug in minimum quantity of dimethyl formamide (DMF) and finally, diluted with $6.8 \mathrm{pH}$ PBS, to make the volume up to $100 \mathrm{ml}$. A series of standard drug solution in concentration range of $1-10 \mu \mathrm{g} / \mathrm{ml}$ were prepared by diluting appropriate volumes of standard stock solutions. The scanning for solution of prednisolone and 5-amino salicylic acid were carried out in the range of 200-400 $\mathrm{nm}$ against $6.8 \mathrm{pH}$ PBS solution as a blank for obtaining the individual absorption spectra (as shown in figure $3 \&$ 4) as well as overlain spectra (as shown in figure 5) that were used in the analysis. 
Journal of Applied Pharmaceutical Science 02 (06); 2012: 222-226

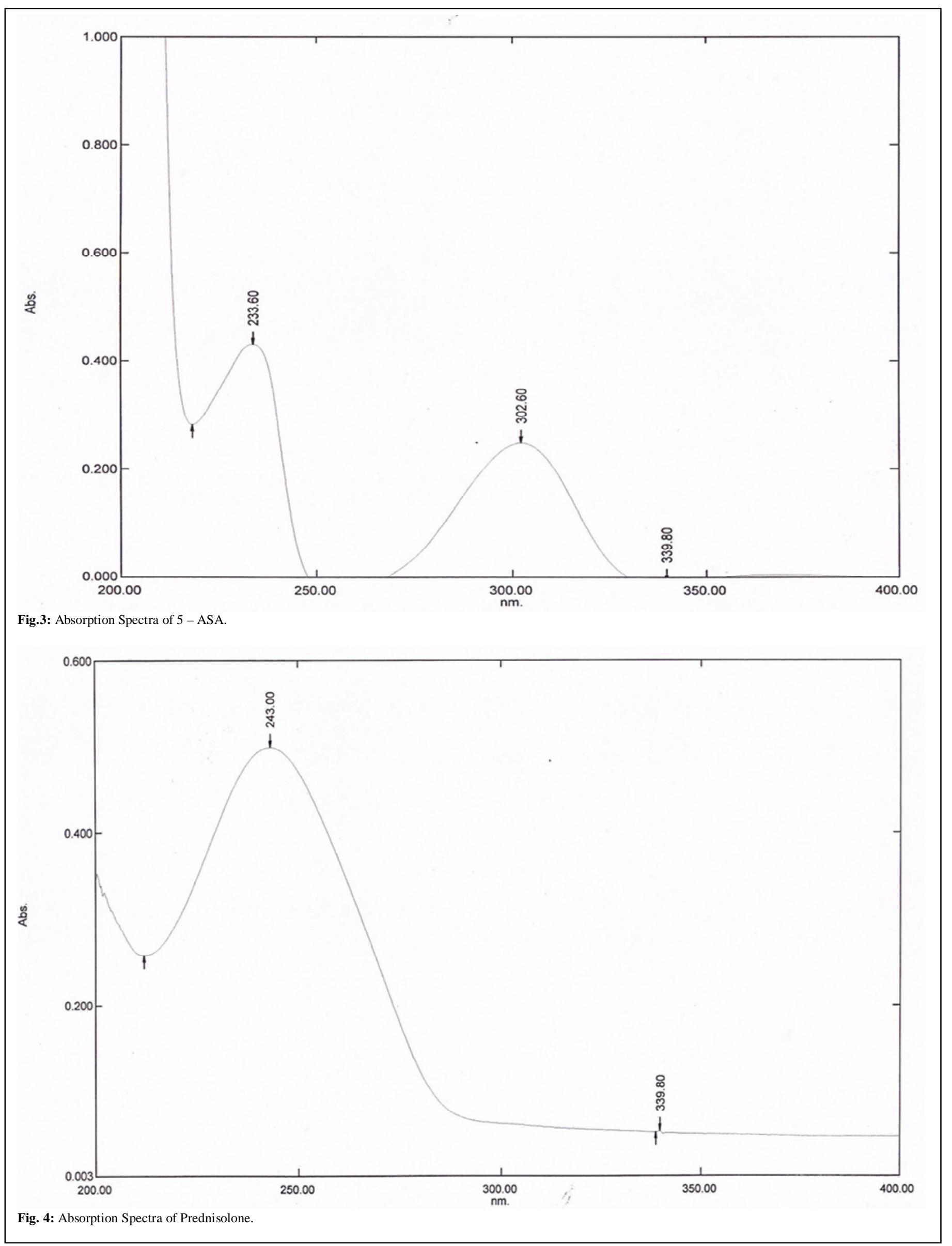




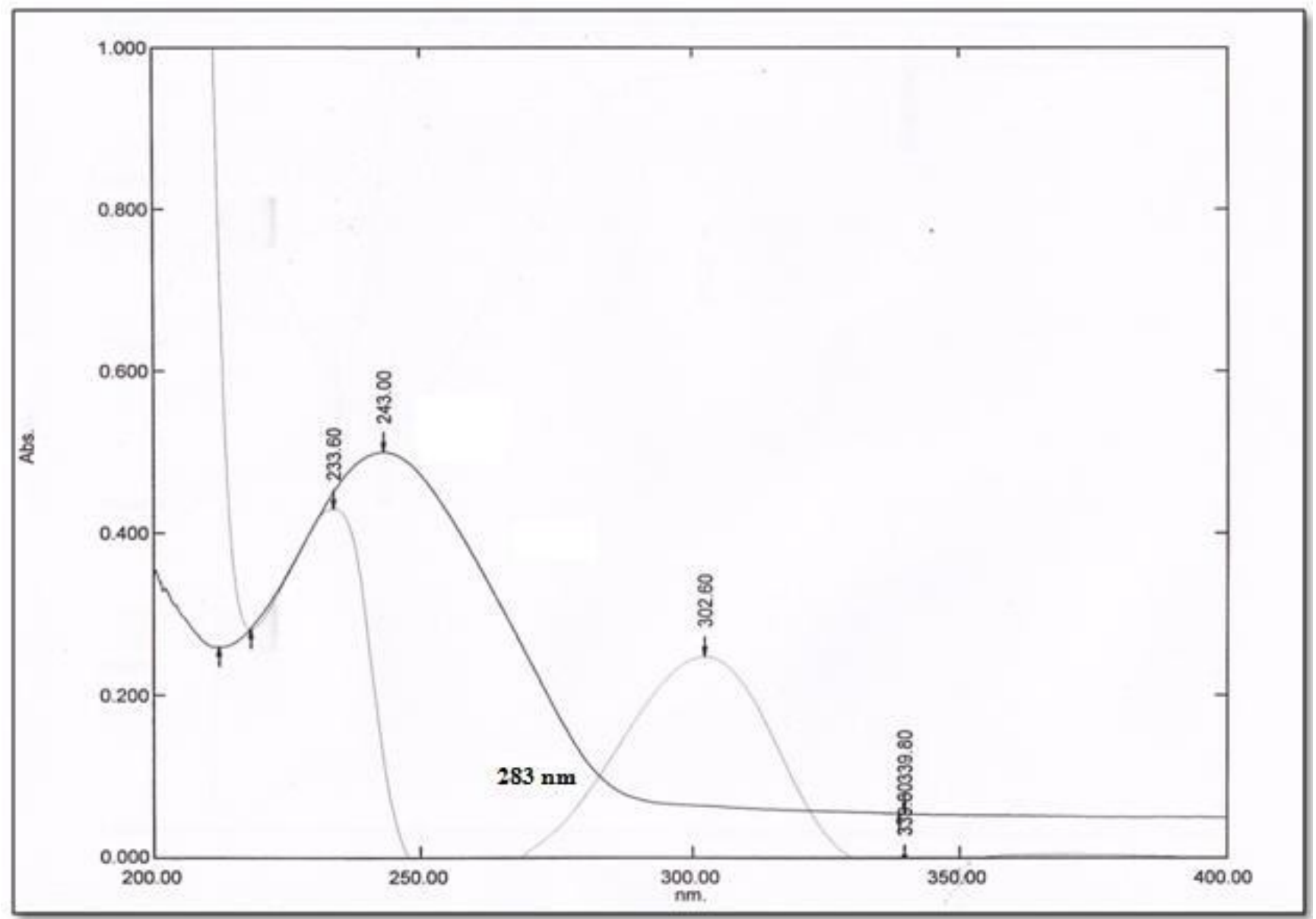

Fig. 5: Overlain spectra of 5-ASA and Prednisolone.

The maximum absorption ( $\lambda \max )$ of 5-ASA was found at $302 \mathrm{~nm}$ and iso-absorptive point at $283 \mathrm{~nm}$. Absorption and absorptivity for a series of standard solutions were recorded at selected wavelengths.

\section{Methodology}

Absorption ratio method uses the ratio of absorptions of two selected wavelength, one of which is iso-absorptive point and other being the $\lambda \max$ of one of the two components. From the overlain spectra of two drugs (as shown in figure 5), it shows that prednisolone and 5-amino salicylic acid having iso-absorptive point at $283 \mathrm{~nm}$. The second wavelength used is $302 \mathrm{~nm}$, which is the $\lambda \max$ of 5 -amino salicylic acid. Working standard solutions having concentration $1,2,3,4,5,6,7,8,9$ and $10 \mu \mathrm{g} / \mathrm{ml}$ for prednisolone and 5-ASA were prepared in $6.8 \mathrm{pH}$ PBS and the absorbance at $283 \mathrm{~nm}$ (iso-absorptive point) and $302 \mathrm{~nm}$ ( $\lambda$ max of 5-ASA) were measured and absorptivity coefficient were calculated using calibrations curve.

The concentration of two drugs in the mixture can be calculating by using the equation $(8 \& 9)$, we get

$\mathrm{Cx}=\left\{\left(\mathrm{Q}_{\mathrm{M}}-\mathrm{Qy}\right) /(\mathrm{Qx}-\mathrm{Qy})\right\}^{*}\left(\mathrm{~A}_{1} / \mathrm{ax}_{1}\right)$

$\mathrm{Cy}=\left\{\left(\mathrm{Q}_{\mathrm{M}} \mathrm{Q} \mathrm{Qx}\right) /(\mathrm{Qy}-\mathrm{Qx})\right\} *\left(\mathrm{~A}_{1} / \mathrm{ay}_{1}\right)$

where, $A_{1}$ and $A_{2}$ are the absorbance of mixture at $283 \mathrm{~nm}$ and 302 $\mathrm{nm} ; \mathrm{ax}_{1}$ and $\mathrm{ay}_{1}$ are absorptivities of prednisolone and 5-amino salicylic acid at $283 \mathrm{~nm} ; \mathrm{ax}_{2}$ and $\mathrm{ay}_{2}$ are absorptivities of prednisolone and 5-amino salicylic acid at $302 \mathrm{~nm} ; \mathrm{Q}_{\mathrm{M}}=\mathrm{A}_{2} / \mathrm{A}_{1}$, Qx $=\mathrm{ax}_{2} / \mathrm{ax}_{1}, \mathrm{Qy}=\mathrm{ay}_{2} / \mathrm{ay}_{1}$.

\section{Validation of proposed method} Linearity

Linearity was evaluated by preparing different concentration in the range of $1-10 \mu \mathrm{g} / \mathrm{ml}$ for both the drugs and absorption was measured. Each measurement was carried out in triplicate.

\section{Accuracy (Recovery studies)}

In order to check the accuracy, reproducibility and precision of the proposed method, recovery study was carried out by taking standard mixture solution of both prednisolone and 5amino salicylic acid (as shown in Table 1).

Table. 1: Recovery study data of prednisolone and 5-ASA.

\begin{tabular}{llll}
\hline $\begin{array}{c}\text { Prednisolone } \\
(\boldsymbol{\mu g} / \mathbf{m l})\end{array}$ & $\begin{array}{c}\text { 5-ASA } \\
(\boldsymbol{\mu g} / \mathbf{m l})\end{array}$ & $\begin{array}{l}\text { Prednisolone }(\% \\
\text { Recovery })\end{array}$ & $\begin{array}{l}\text { 5-ASA }(\% \\
\text { Recovery })\end{array}$ \\
\hline 4 & 4 & $99.03 \pm 0.16$ & $99.30 \pm 0.25$ \\
8 & 8 & $99.63 \pm 0.19$ & $99.09 \pm 0.67$ \\
12 & 12 & $98.83 \pm 0.39$ & $101.02 \pm 0.48$ \\
16 & 16 & $98.69 \pm 0.58$ & $98.44 \pm 0.39$ \\
\hline
\end{tabular}

Results are shown as mean \pm S. D $(n=3)$ 


\section{Method Precision (Repeatability)}

The precision of the instrument was checked by repeated scanning and measurement of absorbance of solutions $(\mathrm{n}=3)$ for prednisolone and 5-ASA $(10 \mu \mathrm{g} / \mathrm{ml}$ for both drugs) without changing the parameter of the proposed spectrophotometry method (as shown in Table 2).

Table 2: Regression analysis data

\begin{tabular}{llll}
\hline \multicolumn{1}{c}{ Parameter } & Prednisolone & \multicolumn{1}{c}{ 5-ASA } & $\begin{array}{c}\text { Prednisolone } \\
\text { \& 5-ASA }\end{array}$ \\
\hline Wavelength $(\mathrm{nm})$ & 302 & 302 & 283 \\
Beer's law limit $(\mu \mathrm{g} / \mathrm{ml})$ & $1-10$ & $1-10$ & $1-10 \& 1-10$ \\
Regression equation $(\mathrm{y}=$ & $\mathrm{y}=0.006 \mathrm{x}-$ & $\mathrm{y}=0.023 \mathrm{x}$ & $\mathrm{y}=0.015 \mathrm{x}-$ \\
$\mathrm{mx}+\mathrm{c})$ & 0.001 & -0.000 & $0.002 \& \mathrm{y}=$ \\
& & & $0.015 \mathrm{x}-0.002$ \\
Slope $(\mathrm{m})$ & 0.006 & 0.023 & 0.015 \\
Intercept $(\mathrm{c})$ & -0.001 & 0.000 & -0.002 \\
Correlation coefficient $\left(\mathrm{R}^{2}\right)$ & 0.993 & 0.999 & 0.997 \\
Precision $(\mathrm{n}=3)$ & 0.082 & 0.274 & 0.135
\end{tabular}

\section{RESULTS AND DISCUSSION}

In absorbance ratio method (Q-analysis), the primary requirement for developing a method for analysis is that the entire spectra should follow the Beer's law at all the wavelength, which was fulfilled in case of both these drugs. The two wavelengths were used for the analysis of the drugs were $283 \mathrm{~nm}$ (iso-absorptive point) and $302 \mathrm{~nm}(\lambda$-max of 5-ASA) at which the calibration curves were prepared for both the drugs. The overlain UV absorption spectra of prednisolone $(243 \mathrm{~nm})$ and 5-ASA (302 $\mathrm{nm})$ showing iso-absorptive point $(283 \mathrm{~nm})$ in ethanol and $0.1 \mathrm{~N} \mathrm{HCl}$ is shown in Figure 5. The validation parameters were studied at all the wavelengths for the proposed method. Accuracy was determined by calculating the recovery and the mean was determined (as shown in Table 1). Precision was calculated as repeatability for both the drugs (as shown in Table 1). Hence, the method can be employed for the routine analysis of these two drugs in combined dosage form.

\section{CONCLUSION}

The proposed absorption ratio method was found to be simple, sensitive and accurate method for determination of prednisolone and 5-amino salicylic acid in the tablet dosage form. In this method the solvent used will be easily available and cheap for the analysis of prednisolone and 5-ASA hence, this method was also economic for estimation of tablet dosage form. The common excipients and other additives were used in that formulation that doesn't interfere in the analysis of the tablet dosage form. So, we can say that this method is adopted for combined dosage form in the pharmaceutical dosage form.

\section{ACKNOWLEDGEMENT}

The authors thankful to Mr. Pardeep Singla, La-Pharma, Ludhiana (INDIA) for supplying gift samples of prednisolone. We are grateful to Director, Dr. A.K. Sharma and Head of department, Dr. Mahendra Singh Rathore, CT Institute of Pharmaceutical Sciences, Jalandhar for encouragement and stimulating discussions.

\section{REFERENCE}

Beckett A.H. and Stenlake J.B. Practical Pharmaceutical Chemistry. $4^{\text {th }}$ ed. - Part One. Published by CBS Publishers and Distributors, New Delhi, India (2005) 133-136.

Beckett A.H. and Stenlake J.B. Practical Pharmaceutical Chemistry. $4^{\text {th }}$ ed. - Part Two. CBS Published by Publishers and Distributors, New Delhi, India (2005) 275-306.

Indian Pharmacopoeia. Vol 2. Published by Controller of publications, New Delhi (1996), 615-616.

Indian Pharmacopoeia. Vol 1. Published by Controller of publications, New Delhi (2007), 112-114.

Kalsi, P.S. In: Spectroscopy of organic compounds. $5^{\text {th }}$ ed. Published by New Age International, New Delhi, (2002) 7-8.

Mendham J., Denney R.C., Barnes J.D., Thomas M.J.K. Vogel's Quantitative Chemical Analysis. $6^{\text {th }}$ ed. Published by Pearson Education, Delhi, India (2004) 630-636. 